\title{
SYMPOSIUM
}

\section{is the good polity attainable? - measuring the quality of democracy}

\section{antónio costa pinto *, pedro c. magalhães and luís de sousa}

Institute of Social Sciences of the University of Lisbon, Av. Professor Aníbal de

Bettencourt, 9, Lisbon 1600-189, Portugal.

E-mails: acpinto@ics.ul.pt, pedro.magalhaes@ics.ul.pt, luis.sousa@ics.ul.pt

${ }^{*}$ Corresponding author.

doi:10.1057/eps.2011.45; published online 16 December 2011

\section{Abstract}

This article introduces a discussion on defining, measuring, and assessing the quality of democracy. Providing a short overview of the papers of the Symposium, it places them within a broader context of current academic debate on various methodological, theoretical, and policy outreach dimensions of the topic.

Keywords quality of democracy; democratisation; competition

\section{INTRODUCTION}

$\mathrm{T}$ he study of democratic regimes by scholars of comparative politics has experienced several interesting turns in the last four decades. In the 1970s and 1980s, developments in Southern European and Latin American countries prompted a concern with regime change, i.e., with 'transitions to democracy'. As the Third Wave of democratisation spread to other parts of the world, scholars shifted their focus to 'democratic consolidation': 'from the ways in which democratic regimes come into being to the ways in which they can be rendered stable and secure' (Plattner,
2005: 77). Today, a double concern seems to prevail. On the one hand, the regression to authoritarianism after processes of democratisation, and the emergence of semi-democracies or hybrid regimes, has provoked a new interest in the study of dictatorships and competitive authoritarianism (Levitsky and Way, 2010). But on the other hand, this does not mean that the study of the dynamics of democracy has lost its appeal. With the end of the Cold War and the expansion of liberal democracy world wide, ${ }^{1}$ academics and practitioners have begun to reflect upon a new concern: neither the 'transition' to democracy nor the 'consolidation' of democracy, but rather the 
'quality(ies) of democracy (QoD)'. As Przeworski (Przeworski, 2010: xii) writes, 'having followed liberalization, transition and consolidation, we have discovered that there is something still to improve: democracy'.

Considerable methodological developments have been made in this new field of democracy studies. Various types of measurements and assessments have been developed and applied to democracies displaying different degrees of consolidation (O'Donnell et al, 2004). Most QoD measurements/assessments are moved, however, by one common goal: to learn what makes a democracy 'better' or 'worse' and to provide decision-makers and other agents of reform insights on how it can be improved and strengthened (Diamond and Morlino, 2005; Morlino, 2006). The symposium we introduce aims at discussing the current efforts in defining, measuring, and assessing $\mathrm{QoD}$, reflecting on the various methodological, theoretical, and policy outreach dimensions of QoD.

\section{UNTANGLING THE CONCEPTS}

Any QoD measurement needs to start with a definition of the two terms that make this complex and multidimensional concept: democracy and quality. Democracy is by no means a consensual concept. But perhaps the most prominent and used definition is the one by Dahl (1989: 221) who, in his famous work Democracy and its Critics, sets out seven principles of his ideal type democracy, which he terms 'polyarchy':

1. The existence of constitutionally bound elected officials who control government decisions about policy;

2. The regular practice of free and fair elections as a mechanism to oppose and vote out the highest officials in government conducted in a way in

\section{'Democracy is by no means a consensual concept'.}

which the use of coercion is comparatively uncommon;

3. This suffrage must be universal and inclusive: practically all adults have the right to vote (active electoral capacity) and...

4. To stand for elective office (passive electoral capacity), though for some elective offices, such as presidential ones, we may have higher age limits for eligibility than we may have for the capacity to vote;

5. The existence of freedoms and guarantees, that enable citizens to express themselves without fear of reprisals or severe punishments on their political ideas and positioning, including their criticism of officials, the government, the regime, the socioeconomic order, and the prevailing ideology;

6. Citizens must also have the right to seek alternative sources of information that must be regulated and protected by law;

7. And they have equally the right to form relatively autonomous associations, including independent political parties and interest groups, to achieve their various rights, including those listed above.

The definition has been enriched by other contributions (Schmitter and Karl, 1991; Morlino, 2006; O'Donnell, 2010; Przeworski, 2010), but its essence has remained unaltered: Dahl's polyarchy offers a procedural conceptualisation of democracy. And yet, it may be argued that, as a system of government, democracy is not characterised solely by a set of basic rules and procedures establishing who is entitled to take collective decisions under what processes. It is also an 
historically built set of fundamental values and a complex mixture of institutions that have put those principles into practice with greater and lesser success (Bobbio, 1988; Beetham, 1994; Mény, 1999). In this sense, we could argue that Dahl's polyarchy is not the arrival but the departure point. As Coppedge (2004: 240) put it, polyarchy is 'a minimal acceptable degree of democracy'.

How do we move from 'democracy' to 'quality of democracy'? By 'quality' Larry Diamond and Leonardo Morlino (2005: xi) suggest three meanings with different implications to its measurement: procedure quality, in which the quality of a product 'is the result of an exact, controlled process carried out according to precise, recurring methods and timing'; content quality, i.e., quality that results from 'the structural characteristics of a product, such as its design, materials, or functioning'; and result quality, the quality of a product or service 'directly indicated by the degree of customer satisfaction with it, regardless of how it is produced or its actual content'.

Following on these definitions, the authors conceptualise 'quality democracy' as a regime whereby citizens are granted

a high degree of freedom, political equality, and popular control over public policies and policy makers through the legitimate and lawful functioning of stable institutions. In this line, a 'good' democracy is primarily a broadly legitimated regime that satisfies citizens' expectations of governance (quality in terms of result). A 'good democracy' is also one in which its citizens, associations, and communities enjoy extensive liberty and political equality (quality in terms of content). Finally, a 'good' democracy is also a regime in which citizens have the sovereign power to evaluate whether the government provides liberty and equality according

\section{'...there is room for inconsistencies and tradeoffs between the various dimensions of QoD'.}

to the rule of law. Citizens, their organisations and parties participate and compete to hold elected officials accountable for their policies and actions. They monitor the efficiency and fairness of the application of the laws, the efficacy of government decision, and the political responsibility and responsiveness of elected officials. Government institutions also hold one another accountable before the law and the constitution (quality in terms of procedure) (Diamond and Morlino, 2005: $x i)$.

However, this definition of QoD raises three misconceptions. First, there is a general presumption that the various dimensions of democratic governance procedural, normative or result based should perform in a harmonious way. The belief that somehow these different dimensions would converge and evolve towards an ideal type polity remains a utopia. Historical evidence teaches us that no democracy can be equated to such an ideal type polity. Comparative analysis demonstrates that there is room for inconsistencies and tradeoffs between the various dimensions of QoD. As Diamond and Morlino (2005: xxxii-xxxiii) put it, 'To be sure, all good things do not go together smoothly. [...] A high-quality democracy thus is not indefinitely high in every democratic quality'. Democracy is a sufficiently elastic concept and political reality to deal and live with these inconsistencies, products of unfinished modernisation processes. As Mény (1999: 115) puts it succinctly: 'What we traditionally 
and readily call "democracy" is a system that closely blends democratic and nondemocratic elements in combinations that vary in time and space, subject continually to an examination of their legitimacy before the elites in particular and the people in general'.

Second, there is a widespread belief that people have a common understanding of these standards in a given society and across countries. However, when assessing QoD, one should bear in mind that cognitive levels about the structure and process of democracy are substantially different across different social groupings, in particular between those who hold office and those upon who authority is exercised. Citizens organise their knowledge about democracy through abstract mental frames, fed by a variety of sources (in the forefront the media, but also social groups of all kinds, books, internet and so on), with different degrees of sophistication and consistency. These mental frames represent their understanding of the way democracy is organised and operates. In other words, people resort to schemata to organise current knowledge and provide a framework for the understanding of the future of democracy.

By contrast, the perceptions of politicians are more endogenous to the political system and for that reason tend to express a more elaborate and informed vision of its modus operandi. This contrast in cognitive levels is fundamental to the understanding of support for, and legitimacy, of democracy. It is important to distinguish between perceptions on the performance of democratic rule held by an actor with direct (even if loose) responsibilities for its functioning from those held by citizens at large, who are largely kept at bay from politics and are only asked to interact with it during elections (and only exceptionally via referenda or other forms of institutionalised participation).

\section{'...scholarly definitions of "quality of democracy" do not always reflect people's expectations'.}

Similarly, variations across societies and cultures regarding the meanings and understandings of democracy are also likely to be considerable. Interestingly, in line with what we have been arguing so far, it seems that, when prompted to define democracy, pluralities of citizens across very different countries seem to focus on freedom and civil liberties. In other words, 'people seem to understand that electoral and constitutional democracy is not sufficient. To most people, the real meaning of democracy is in what it produces' (Dalton et al, 2007: 147). However, it is also the case that, in some countries, definitions of democracy based on 'social equality and justice' compete in prominence with others (Dalton et al, 2007: 147; see also Camp, 2001). Different cultural traits and patterns of institutional and/or socio-economic development help to explain variations in citizens' perceptions, acquiescence and appropriation of democratic standards. People who have experienced deliberative democracy longer may associate a different value to participation than those who are only called to cast their vote every 4 years. People who have lived until recently under authoritarianism are likely to give a higher value to transparency, whereas those who live under stringent economic conditions may believe transparency and responsibility are secondary to efficiency. And so on.

The notion that different individuals, different groups and different mass publics hold different beliefs about the meaning of democracy raises a third and final issue: scholarly definitions of 'QoD' do not always reflect people's 
expectations. There is a rather difficult balance to strike here in this respect. On the one hand, this raises a problem for QoD measurements that do not take public opinion indicators on board. It is not surprising that a given democracy may score high in the various QoD dimensions as 'objectively' measured, but that its citizens may still feel dissatisfied with their regime's performance. Even if we try to explain such discrepancy as a result of the citizens' low cognitive capacity to understand policies/politics, their vulnerability to media sensationalism, the diversity of interests and concerns (and their variable aggregation) in society and the inherent tendency of citizens to always be unsatisfied with what they get, this does not stop them from judging the quality of their own democracy when confronting its modus operandi with the mechanisms and performances of other regimes. As Plattner (2005: 78, 81) alerts us, the selection of standards/indicators for the purposes of measuring or auditing QoD is often biased, because it imposes the particular political preferences of scholars 'as objective standards of quality' upon native citizens from those regimes under scrutiny. Citizens may display partial, distorted and less sophisticated notions of democracy, but every single individual has a vision of the regime or society they would like to live in, which may be less 'democratic' or expressing a different sort of democracy than the one scholars would have expected. More than being a disputed concept, democracy is a process in constant redefinition. Hence the need to establish valid, meaningful, and reliable ways to measure and assess democratic progress is quintessential to both decision-makers and citizens at large to evaluate in which direction their democracy is evolving (Diamond and Morlino, 2005).

On the other hand, we should be wary of overstretching concepts or to

\section{'More than being a disputed concept, democracy is a process in constant redefinition'.}

relativise them too much, leaving to citizens who, in some cases, may not even have experienced the functioning of a procedurally democratic regime, the task of defining what researchers want to measure, lest we run the risk of loosing comparability and, worse than that, loosing track of what we were trying to measure in the first place. Instead, as Coppedge (2004: 241) suggests, researchers are responsible for converting citizens' interests and visions of democracy into analytical, useful socio-scientific concepts 'by deciding which of these concepts can be naturally articulated in a coherent theoretical framework'.

\section{THE QUEST FOR QOD METRICS}

Notwithstanding these conceptual difficulties, there has been an increased interest in QoD assessments from a variety of actors (decision-makers, democracy promoters, academics and so on). There are various epistemological and praxeological objectives associated with QoD measurements, but these can be grouped into three major goals: an informative goal, as citizens and decision-makers want to know how strong their democracy is; a comparative goal, as they also want to know whether the regime they live in is more or less democratic than those of their neighbours; and a policy goal, as decision-makers and democracy promoters want to know how their democratic institutions and practices respond to popular aspirations and what aspects are underperforming in order to implement the necessary reforms and adjustments. 
As Plattner (2005: 31) put it, from the practical standpoint, the exercise of assessing the state, performance or QoD is 'a useful innovation that can aid citizens evaluating their own democracies'.

Some of the early studies on QoD (Diamond and Morlino, 2005) discussed various procedural and substantive dimensions of democratic governance the rule of law, accountability, inequality, and responsiveness - but failed to provide a general framework for measuring QoD. The initial concern about QoD was fundamentally a response to the citizens' lack of knowledge, interest and participation in politics (Geissel, 2008: 366).

The first and most influential general approach to measuring QoD was developed by David Beetham. Starting from a set of substantive dimensions, Beetham (2005: 42) proposed a four-step theoretical framework to assess the quality of a country's democracy:

- First, by identifying for empirical investigation and analysis, the relevant items that together comprise a 'good' democracy;

- Second, by comparing those items against international standards of best practice;

- Third, by checking the items for typical subversions, combined with an appraisal of how their practice is perceived by citizens themselves; and

- Fourth, by analysing how well the protective agencies guard against these typical subversions.

Beetham's Democratic Audit approach was developed further under the auspices of the International Institute for Democracy and Electoral Assistance (IDEA) in Stockholm. IDEA tested the framework in eight countries and updated its methodology and indicators to include other dimensions of analysis, which were not foreseen in the initial model. For instance, more attention was paid to institutions of federalism and to conflict between democratic values.

Further to these qualitative countrybased assessments, there has been the development of large $N$ measurements aimed at general theorising and the explanation of observable regularities/ variations across different countries. These innovative approaches include the works of Vanhanen (1997), Altman and Pérez-Liñán (2002), Andreev (2005), Berg-Schlosser (2006), and Ringen (2007). In their hard and endless task of mapping and explaining QoD, these authors 'have adopted a number of strategies to measure democracy, including categorical measures (democracy versus non-democracy), scale measures (e.g., a rating on a 1 to 10 scale), objective measures (e.g., voter turnout and party share of the vote), hybrid measures of democratic practices, and perceptions of democracy based on mass public opinion surveys' (IDEA/Landman, 2008).

We will not be assessing the merits and demerits of each of these tentative measurements, since it is not the purpose of this introduction. Instead we will concentrate on the various theoretical and methodological developments and approaches discussed in this Symposium.

The Institute of Social Sciences of the University of Lisbon (ICS-UL) organised in 2010, a symposium on the theoretical, empirical and practical issues involved in assessing QoD, under the aegis of the Barometer of the Quality of Democracy, a project led by António Costa Pinto at ICSUL. The contributions to this symposium share, in different degrees, a concern with the informative, comparative, and policy goals stated above, and all aim at critical reflection on the existing QoD exercises and present new theoretical, methodological and policy outreach solutions for the quest for QoD metrics.

In his contribution, Todd Landman takes a comprehensive approach to QoD assessment, combining conceptual, 
methodological and policy outreach pillars in the democracy assessment framework. According to Landman, five main functions are thus served: (1) description, (2) classification, (3) hypothesis testing, (4) prediction and policy advice, and (5) advocacy and reform. He describes the main principles of this framework developed by International IDEA, and reflects on its application in over twenty-five countries. Placing citizens at the forefront of the democracy assessment, he argues that a QoD assessment framework should not be merely a measurement exercise, but should perform a policy outreach function by proving countries with a practical tool for initiating democratic reforms and consolidating democratic practices.

The contribution by Carolyn Logan and Robert Mattes addresses one of the crucial challenges we identified early on: the need to measure the 'lived experiences and subjective evaluations of ordinary citizens' in what concerns democracy and to integrate them in any assessment of QoD. Starting from Diamond and Morlino's (2005) three-faceted definition of quality (procedure, content, and result), they investigate the degree to which public evaluations can be deployed to measure not only the 'responsiveness' dimension (i.e., quality of the result), but also the 'procedural' and 'substantive' ones. Using Afrobarometer data, Logan and Mattes find that ordinary Africans provide meaningful evaluations of the overall supply QoD and also distinguish between various dimensions of democratic performance in ways that largely replicate the Diamond and Morlino framework. Although holding that objective data and expert evaluations need to play a central role in QoD assessment, they show that the discrepancies between them, and the subjective judgments made by citizens, are crucial and intriguing objects of study in and of themselves.
Like Logan and Mattes, Bráulio Gomez and Irene Palacios build their QoD assessment on Diamond and Morlino's approach. And also like Logan and Mattes, they place citizens and their views about QoD at the centre of their research, developing an empirical application of Diamond and Morlino's normative framework and applying it to an evaluation of the quality of a national democracy, concretely, Spain. The importance of their exercise resides in the development of an original survey specifically designed for this purpose, which assesses the performance of Spanish democracy, as subjectively perceived by citizens, according to eight dimensions: rule of law, electoral accountability, inter-institutional accountability, participation, competition, liberty, equality and sensitivity (or responsiveness). Their results clearly show that citizens have a multi-dimensional view of the quality of their democracy, and that generic measures of evaluation of democracy's performance are likely to miss out on crucial distinctions that both citizens and experts are able to make.

Finally, the contributions of Heiko Giebler, as well as of Marc Bühlmann, Wolfgang Merkel, Lisa Müller, and Bernhard Weßels are chiefly concerned with the daunting methodological and methodical challenges of measuring democracy and its quality, namely its conceptualisation, measurement, and aggregation. They argue that a substantive theoretical perspective is a necessary, but not sufficient, condition for improving QoD exercises, which should be accompanied by an equally welldeveloped effort in measurement. Giebler discusses a number of problems in existing measures, including the Freedom House civil liberties and political rights assessments and the Bertelsmann Transformation Index, namely related to the absence of transparent reliability tests, small number of expert judgements involved, scaling and standardisation issues, 
and aggregation rules. Overall, he shows that there is much potential for the improvement of existing QoD measures in terms of reliability and validity. By recognising the shortcomings and their effects, researchers will be able to increase the quality of any analysis using even imperfect measures. Bühlmann et al present the methodology of the Democracy Barometer (DB) developed by the Centre for Democracy Aarau (ZDA) in Switzerland, examine its descriptive purposes and demonstrate the potential of this new instrument for overcoming the conceptual and methodological shortcomings of previously existing QoD indices.
Particularly crucial is DB's ability to capture variation within established democracies, something that many current objective indicators fall short of accomplishing. This is demonstrated by an application of the methodology and measurement strategy to three illustrative cases, Finland, Italy, and the United States.

\section{Acknowledgements}

A special word of gratitude goes out to Professor Alfred Tovias for his invaluable help in providing the information for this article.

\section{Note}

1 'At mid-century, there were 22 democracies accounting for 31 per cent of the world's population and a further 21 states with restricted democratic practices, for 11.9 per cent of the globe's population. By the close of our century liberal and electoral democracies clearly predominate, and have expanded significantly in the Third Wave, which has brought democracy to much of the post-Communist world and to Latin America and parts of Asia and Africa. Electoral democracies now represent 119 of the 192 existing countries and constitute 58.2 per cent of the world's population. At the same time liberal democracies - i.e. countries Freedom House regards as free and respectful of basic human rights and the rule of law - are 85 in number and represent 38 per cent of the global population' (Freedom House Democracy's Century Report, 1999. Available online: http://www.freedomhouse.org/reports/century.pdf).

\section{References}

Altman, D. and Pérez-Liñán, A. (2002) 'Assessing the quality of democracy: Freedom, competitiveness, and participation in eighteen Latin American countries', Democratization 8(2): 85-100.

Andreev, S.A. (2005) Conceptual Definitions and Measurement Indicators of the Quality of Democracy: An Overview. EUI Working Papers/RSCAS 2005/05, ISSN 1028-3625.

Beetham, D. (ed.) (1994) Defining and Measuring Democracy, Vol. 36, SAGE Modern Politics Series London: SAGE.

Beetham, D. (2005) 'Freedom as the Foundation', in L. Diamond and L. Morlino (eds.) Assessing the Quality of Democracy, Baltimore: The John Hopkins University Press, pp. 32-46.

Berg-Schlosser, D. (2006) 'The Quality of Democracies in Europe as Measured by Current Indicators of Democratization and Good Governance', in D. Hutcheson and E. Korosteleva (eds.) The Quality of Democracy in Post-Communist Europe, London/NY: Routledge, pp. 28-55.

Bobbio, N. (1988) O Futuro da Democracia, Lisboa: Publicações Dom Quixote.

Camp, R.A. (ed.) (2001) Citizen Views of Democracy in Latin America, Pittsburgh: University of Pittsburgh Press.

Coppedge, M. (2004) 'Quality of Democracy and Its Measurement', in G. O'Donnell, J.V. Cullell and O.M. Iazzetta (eds.) The Quality of Democracy: Theory and Applications, Notre Dame: University of Notre Dame Press, pp. 239-248.

Dahl, R. (1989) Democracy and its Critics, New Haven: Yale University Press.

Dalton, R.J., Shin, D.C. and Jou, W. (2007) 'Understanding democracy: Data from unlikely places', Journal of Democracy 18(4): 142-156.

Diamond, L. and Morlino, L. (eds.) (2005) Assessing the Quality of Democracy, Baltimore: The John Hopkins University Press. 
Geissel, B. (2008) 'Migliorare la Qualità delle Democrazia a Livello Locale: Esperienze Innovative di Democrazia Partecipativa in Germania', Rivista Italiana di Scienza Politica 38(3): 365-391.

Landman, T. (ed.) (2008) Assessing the Quality of Democracy: An Overview of the International IDEA Framework, (with the contributions of David Beetham, Edzia Carvalho and Stuart Weir), Stockholm: IDEA - International Institute for Democracy and Electoral Assistance.

Levitsky, S. and Way, L. (2010) Competitive Authoritarianism, New York: Cambridge University Press.

Mény, Y. (1999) 'Five (hypo)theses on democracy and its future', Progressive Governance for the XXI Century, Conference Proceedings, 20-21 November 1999, Florence: EUI and NYU Law, pp. 111-126.

Morlino, L. (2006) 'Good' and 'Bad' Democracies: How to Conduct Research into the Quality of Democracy', in D. Hutcheson and E. Korosteleva (eds.) The Quality of Democracy in Post-Communist Europe, London/NY: Routledge, pp. 5-27.

O'Donnell, G. (2010) Democracy, Agency, and the State: Theory with Comparative Intent, Oxford: Oxford University Press.

O'Donnell, G., Cullell, J.V. and Iazzetta, O.M. (eds.) (2004) The Quality of Democracy: Theory and Applications, Notre Dame: University of Notre Dame Press.

Plattner, M. (2005) 'A Skeptical Perspective', in L. Diamond and L. Morlino (eds.) Assessing the Quality of Democracy, Baltimore: The John Hopkins University Press, pp. 77-81.

Przeworski, A. (2010) Democracy and the Limits of Self-Government, New York: Cambridge University Press.

Ringen, S. (2007) What Democracy Is For? On Freedom and Moral Government, Princeton, NJ: Princeton University Press.

Schmitter, P.C. and Karl, T.L. (1991) 'What democracy is... and is not', Journal of Democracy 2(3): 75-88. Vanhanen, T. (1997) Prospects of Democracy: A Study of 172 Countries, London: Routledge.

\section{About the Authors}

António Costa Pinto is a Research Professor at the Institute of Social Sciences, University of Lisbon. His research interests include authoritarianism, democratisation and transitional justice in new democracies, the European Union, and the comparative study of political change in Europe. He co-edited recently (with Leonardo Morlino) Dealing with the Legacy of Authoritarianism: The 'Politics of the Past' in Southern European Democracies, London: Routledge, 2010.

Pedro C. Magalhães is a Researcher at the Institute of Social Sciences, University of Lisbon. His research focuses on electoral behaviour, political attitudes, public opinion, and judicial behaviour. He has participated in a series of research projects including PIREDEU, InTune, Comparative Study of Electoral Systems, Comparative National Elections Project, and the Portuguese Voting Behaviour Study.

Luís de Sousa is a Researcher at the Institute of Social Sciences, University of Lisbon. He is the President of the Transparência e Integridade, Associação Cívica - a contact point of Transparency International in Portugal. His current research interests focus on corruption and corruption control studies, the politics of ethics reforms, regional integration (institutions and policies), cross-border relations, international organisations and comparative politics in general. 